\title{
Lower Extremity Amputations in Barbados: 1999 and 2009 - Has the Situation Changed?
}

BJ Sumpio ${ }^{1}$, S Belgrave ${ }^{2}$, R Jonnalagadda ${ }^{2}$, D Mahler ${ }^{1}$, A Hennis 2 , O Jordan ${ }^{3}$, BE Sumpio ${ }^{1}$

\begin{abstract}
Objective: Since the seminal publication by Hennis et al that established Barbados as the amputation capitol of the world, there have been numerous initiatives to decrease the incidence of diabetes and diminish leg amputations by establishing better primary care programmes and improving public awareness. The industrialized world has experienced a 20 to $75 \%$ reduction in the incidence of major amputations during the past two decades. We hypothesized that the implementation of these global strategies would also significantly reduce the rate of amputations in Barbados.

Method: A retrospective analysis was undertaken of patients who underwent a lower extremity amputation (LEA) between January 1 and December 31, 2009 at the Queen Elizabeth and Bay View Hospitals by the review of the operating logs and under the guidance of the Ethics Board. Results: A total of 226 LEA were performed in 2009 similar to the number performed in 1999. Diabetes was present in 85\% of the amputees in 2009 compared to only $75 \%$ in 1999. The location of the LEA is shown in the Table.

Conclusion: Despite public health and care-giver diabetes initiatives, there has been no improvement in leg amputations in Barbados. The data suggest that there may be an alarming worsening of the situation because although the numbers of LEA are similar over the decade, there is a much higher percentage of patients with diabetes. Furthermore, there is also a disturbing trend in 2009, with a lower number of minor amputations mirrored by a dramatic increase in proximal leg amputations (AKA/BKA). This may indicate that patients are presenting to their physicians at a later stage of their foot pathology. Further attempts at patient education and establishment of foot screening clinics may be required to reverse this trend.
\end{abstract}

Keywords: Amputations, diabetes, Barbados

\section{Amputaciones de las Extremidades Inferiores en Barbados: 1999 y 2009. ¿Ha cambiado la Situación?}

BJ Sumpio ${ }^{1}$, S Belgrave ${ }^{2}$, R Jonnalagadda ${ }^{2}$, D Mahler ${ }^{1}$, A Hennis $^{2}$, O Jordan ${ }^{3}$, BE Sumpio ${ }^{1}$

\begin{abstract}
RESUMEN
Objetivo: Desde la publicación seminal de Hennis et al, en la se establece a Barbados como la capital mundial de las amputaciones, ha habido numerosas iniciativas para disminuir la incidencia de la diabetes y disminuir las amputaciones de pierna, mediante la creación de mejores programas de atención primaria y el mejoramiento de la conciencia pública. El mundo industrializado ha experimentado una reducción de 20 a 75\% en la incidencia de amputaciones mayores durante las últimas dos décadas. Planteamos la hipótesis de que la aplicación de
\end{abstract}

From: ${ }^{1}$ Yale University School of Medicine, New Haven CT, USA, ${ }^{2}$ University of the West Indies, Cave Hill, Barbados and ${ }^{3}$ Barbados Diabetes Foundation, Warrens, St Michael, Barbados.
Correspondence: Dr BJ Sumpio, 330 Cedar Street, New Haven CT, 06510, USA. Email: Brandon.Sumpio@yale.edu 
estas estrategias globales reduciría también considerablemente la tasa de amputaciones en Barbados

Método: Se realizó un análisis retrospectivo de pacientes que experimentaron amputación de la extremidad inferior (AEI) entre enero 1 y diciembre 31 de 2009 en los hospitales Queen Elizabeth y Bay View, revisando los registros de operaciones, bajo la dirección de la Junta de Ética. Resultados: Se realizaron un total de 226 AEI en 2009, similar al número de las realizadas en 1999. La diabetes estuvo presente en el $85 \%$ de los amputados en 2009, en comparación con sólo el 75\% en 1999. La ubicación de las AEI se muestra en la tabla.

Conclusión: A pesar de la salud pública y las iniciativas de las personas encargadas del cuidado de la diabetes, no ha habido ninguna mejora en las amputaciones de pierna en Barbados. Los datos sugieren que puede haber un empeoramiento alarmante de la situación, porque si bien las cifras de AEI son similares a través de la década, hay un porcentaje mucho mayor de pacientes con diabetes. Además, también hay una tendencia preocupante en 2009, con un número menor de amputaciones menores acompañado por un aumento dramático en las amputaciones proximales de la pierna por encima y por debajo de la rodilla (AER/ADR). Esto bien puede ser un indicio de los pacientes están acudiendo a ver a sus médicos en una etapa tardía de la patología del pie. Otros intentos para la educación del paciente y el establecimiento de clínicas de examen (screening) del pie puede ser necesarios para revertir esta tendencia.

Palabras claves: Amputaciones, diabetes, Barbados

West Indian Med J 2017; 66 (2): 283

\section{INTRODUCTION}

The prevalence of diabetes around the world is expected to double by 2030. Despite the disparities in healthcare systems, nearly every country is affected by this increase. While patients with diabetes have a higher incidence of strokes, kidney disease and hypertension, foot ulcers and leg amputations are amongst the most severe and life changing $(1,2)$. Due to inadequate circulation and neuropathy, small diabetic foot ulcers may quickly transition into life threatening infections and non-healing wounds that result in amputations (3).

The data reported from Barbados in 2004, have listed national amputation rates among the highest reported. Furthermore, this study demonstrated that mortality rates associated with lower extremity amputations, due to diabetes in 1999 were higher than any other population studied and that cardiovascular disease was the principal cause of death following diabetes related amputations (4).

Since that seminal publication, there have been initiatives to decrease the incidence of diabetes-related lower limb amputations by improving primary care networks, promulgating public awareness of footcare and ulcer prevention [step-by-step] (5) and establishing interdisciplinary care teams and centres (Barbados Diabetes Foundation).
With all the notoriety surrounding the high incidence of diabetes and amputations in Barbados (6), we hypothesized that the implementation of these multifaceted strategies would reduce the rate of lower extremity amputations. While the industrialized world has experienced a 20 to $75 \%$ reduction in the incidence of major amputations during the past two decades $(7,8)$, the patterns of lower extremity amputations in Barbados remain undocumented over-time.

\section{METHODS}

Under the Ethics Committee approval, a retrospective study was done by analysing the surgical log books at the Queen Elizabeth Hospital and Bayview Hospital in Barbados to determine the incidence of lower limb amputations in the one-year period between January 1, 2009 and December 31,2009. All the patients who underwent a minor or major lower extremity amputation were assessed for co-existing diabetes. Amputations were classified as minor (toe and foot), or major amputations (below knee, BKA and above knee, AKA amputations). The data about the Barbados population structure in 1999 and 2009 were obtained from the records of the Barbados Ministry of Finance and Barbados Statistical Services Department.

The data about amputations in 2009 were compared to information previously collected by our team in 1999 . 
Statistical analyses were done using SPSS Systems (Armonk, NY). The statistical analyses for total amputations were carried out using Z-scores based on the total number of amputations in both years relative to the total population of those years. The analyses for minor, BKA and AKA were done from $Z$-scores using the number of each specific type of amputation relative to the total number of amputations performed that year, $p$-values were then obtained from the Z-scores.

\section{RESULTS}

In 1999, a total of 225 lower extremity amputations were done in Barbados. One hundred and twenty-three $(54.6 \%)$ of them, were considered minor amputations, while BKA and AKA accounted for 47 (20.9\%) and 35 $(15.5 \%)$ of the amputations, respectively. A total of 169 $(75 \%)$ of the patients in this cohort were diabetic. In 2009 , of the 226 amputations done at the two hospitals in Barbados, 80 (35.4\%) of them, were minor amputations, $79(35.0 \%)$ were BKA and $67(29.6 \%)$ were AKA (Table).

Table: Amputation data

\begin{tabular}{lcll}
\hline & $\mathbf{1 9 9 9}$ & $\mathbf{2 0 0 9}$ & $\boldsymbol{p}$-value \\
\hline Toe & 123 & 80 & $p<0.01$ \\
Below knee amputations & 47 & 79 & $p<0.01$ \\
Above knee amputations & 35 & 67 & $p<0.01$ \\
Total & 225 & 226 & $\mathrm{NS}$ \\
Minor amputations & $69.8 \%$ & $47.7 \%$ & $p<0.01$ \\
Major amputations & $30.2 \%$ & $51.3 \%$ & $p<0.01$ \\
Per cent diabetics & $75 \%$ & $85 \%$ & $p<0.01$ \\
\hline
\end{tabular}

The number of patients who underwent amputations in 2009 and had diabetes mellitus was higher at 192 (85\%). The population estimate for Barbados in 1999 was 267100 while in 2009 the Barbados Statistical Services recorded it as 275400 . While there was no statistical change between the number of amputations being be performed in 1999 and $2009(p>0.05)$, there was a statistical difference between the type of amputations carried out. Additionally, we also recognize a statistical increase in the number of the diabetics receiving amputations.

\section{DISCUSSION}

As shown in Table 1, the incidence of first ever amputations in 1999 and 2009 is statistically similar. At a first glance, this indicates that the public health agenda to reduce lower extremity amputations was ineffective in reducing the number of procedures performed yearly.
However, upon closer inspection of the data, an interesting trend emerges (Figure). While the number of total amputations remained statistically the same, the number of minor amputations dropped by $32 \%$ from 123 to 80 per year. At the same time, major amputations (below and above knee amputations) rose to $78 \%$ from 82 to 146 amputations per year. These data can be interpreted in the context that a decade later, similar numbers of amputations were still being done, but major amputations had increased to now account for over half of all the amputations. This is important since the quality of life associated with minor and major amputations is starkly different (9).

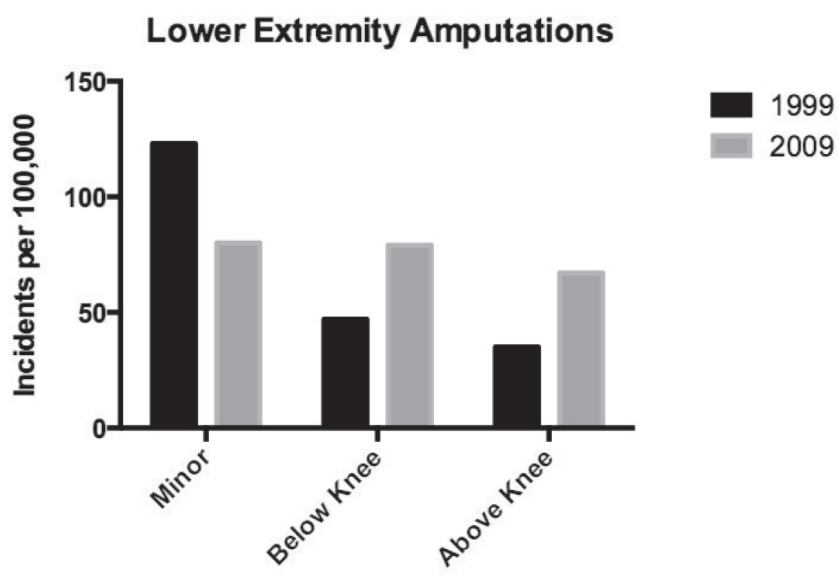

Figure: Lower extremity amputations.

The Figure shows a comparison of lower extremity amputations in 1999 and 2009. While minor amputations decreased from 123 to 80 per year, both above and below knee amputations rose.

While a minor amputation can be debilitating, studies show that a multitude of factors, ranging from the quality of life to even survival, can differ dramatically between minor amputations and above and below knee amputations. For instance, while $26.9 \%$ of individuals with minor amputations have no problem with mobility, only $3.8 \%$ with major amputations claim they have no ambulation issues. Furthermore, while only $23.1 \%$ of the amputees with minor amputations claim they have "some problems" with self-care, $38.5 \%$ of those with major amputations claim they have "some problems" and 15.4\% claim they have "severe problems" with self-care (10).

These facts suggest that not only are the issues getting worse for patients, but - government expenditures could be expected to rise. Individuals who cannot ambulate or take care of themselves may have to rely on government welfare programmes for their needs. They have trouble finding suitable jobs and therefore cannot work, 
and are also likely to rely on their family members to take care of them. As the number of amputations rises, so does expenditure on prosthetic legs for amputees. Currently there is a long waiting list for amputees to receive prosthetics with some waiting more than three years. In that time, patients lose lower extremity muscle mass, knees can become extremely contracted and depression may become more prevalent.

Another troubling observation from the results of the study is that diabetes, the major co-morbidity associated with the amputation cohorts, is increasing. While the national prevalence of diabetes in Barbados has remained fairly constant (now estimated to be $18 \%$ in people above 25 years of age) the data show an increasing prevalence of amputees with diabetes. The proportion of amputees with diabetes increased from $75 \%$ to $85 \%$ between the 10-year interval under review. While many believe this increase is predominantly a result of the "provisions" diet that commonly utilizes starchy agricultural products such as yams, potatoes, cassava, and breadfruit, anecdotally many local practitioners blame the influence of fast food chains on the island.

Based on these data, we suggest that since the initial publication of this article, the diabetic foot health situation in Barbados has not improved during the decade under review. One main reason for this upward trend in major amputations may be the public's perception of doctors and hospitals, in what might be termed the "amputation cycle". As citizens are made aware of Barbados' high-rate of amputations they become hesitant to see their physicians at the early-stages of their lower limb disease believing that they too might be at risk of an amputation. Delays in seeking care for minor problems such as ulcers and cuts may lead to significant worsening of the clinical situation until the problem escalates. This may explain the increasing trend in major amputations over-time, since later presentation to care would be associated with the progression of infections or the wound may have already progressed up the leg and a life-saving major amputation is clinically indicated. As more major amputations are performed, it further reinforces patients' fears of seeing their doctors at an earlier stage of the illness.

However, there are also potential physician factors relevant to this situation (11). Simple routine examinations such as having individuals remove their shoes and checking their feet could lead to an early detection and stifle infections in the early stages. Yet, many physicians around the world ignore this check during their physical examinations of patients (12-14). In addition, informing patients of the importance of wearing the right types of shoes and the complications associated with diabetes along with the importance of foot self-care would also help to alleviate the problem.

\section{CONCLUSION}

Despite public health and care-giver diabetes initiatives, there has been no significant improvement in the number of leg amputations in Barbados. In fact, the data suggest that the situation may be worsening alarmingly, because although the number of amputations has remained relatively constant over the decade, there has been a disturbing trend noted in 2009, with a lower proportion of minor amputations associated with a dramatic increase in proximal leg amputations (AKA/BKA). This may indicate that patients are presenting to their physicians at a later stage of their foot pathology. Further attempts at patient education and establishment of foot screening clinics may be required to reverse this trend. This would be an ongoing process with all the elements of the community involved at the civil society level as well as at the healthcare system level.

\section{REFERENCES}

1. Chin JA, Sumpio BE. Diabetes mellitus and peripheral vascular disease: diagnosis and management. Clin Podiatr Med Surg 2014; 31: 11-26.

2. Hambleton IR, Jonnalagadda R, Davis CR, Fraser HS, Chaturvedi N, Hennis AJ. All-cause mortality after diabetes-related amputation in Barbados: a prospective case-control study. Diabetes Care 2009; 32: 306-7.

3. Sumpio BE. Foot ulcers. N Engl J Med 2000; 343: 787-93.

4. Hennis AJ, Fraser HS, Jonnalagadda R, Fuller J, Chaturvedi N. Explanations for the high risk of diabetes-related amputation in a Caribbean population of black african descent and potential for prevention. Diabetes Care 2004; 27: 2636-41.

5. Abbas ZG, Lutale JK, Bakker K, Baker N, Archibald LK. The 'Step by Step' Diabetic Foot Project in Tanzania: a model for improving patient outcomes in less-developed countries. Int Wound J 2011; 8: 169-75.

6. Adams OP, Carter AO. Knowledge, attitudes, practices, and barriers reported by patients receiving diabetes and hypertension primary health care in Barbados: a focus group study. BMC Fam Pract 2011; 12: 135.

7. Belatti DA, Phisitkul P. Declines in lower extremity amputation in the US Medicare population, 2000-2010. Foot Ankle Int 2013; 34: 923-31.

8. Li Y, Burrows NR, Gregg EW, Albright A, Geiss LS. Declining rates of hospitalization for nontraumatic lower-extremity amputation in the diabetic population aged 40 years or older: US, 1988-2008. Diabetes Care 2012; 35: 273-7.

9. Tang PC, Ravji K, Key JJ, Mahler DB, Blume PA, Sumpio B. Let them walk! Current prosthesis options for leg and foot amputees. J Am Coll Surg 2008; 206: 548-60. 
10. Ragnarson Tennvall G, Apelqvist J. Health-related quality of life in patients with diabetes mellitus and foot ulcers. J Diabetes Complications 2000; 14: 235-41.

11. Adams OP, Carter AO. Are primary care practitioners in Barbados following diabetes guidelines? - a chart audit with comparison between public and private care sectors. BMC Res Notes 2011; 4: 199.
12. McInnes AD. Diabetic foot disease in the United Kingdom: about time to put feet first. J Foot Ankle Res 2012; 5: 26.

13. Walrond ER, Ramesh J. Quality of care of patients with diabetic foot problems in Barbados. West Indian Med J 1998; 47: 98-101.

14. Taylor CG, Jr, Krimholtz M, Belgrave KC, Hambleton I, George $\mathrm{CN}$, Rayman G. The extensive inpatient burden of diabetes and diabetes-related foot disease in Barbados. Clin Med 2014; 14: 367-70. 